\title{
INVENTORY OF TRADITIONAL PROPERTY OF BESEMAH TRIBE IN JOKOH SUB-DISTRICT, DEMPO DISTRICT, PAGAR ALAM CITY
}

By :

Dimas Dwi Arso, Edytiawarman, Slamet Muljono.

\begin{abstract}
This research aims to know and understand the utilization of heritage in indigenous peoples in Besemah tribe, and to know and understand the efforts of indigenous peoples in the tribe of Besemah to preserve their inheritance. In this study the author used an empirical approach by conducting interviews on Jokoh and the head of Adat in the village of Jokoh. As for the material interviewing is about the existence of heirloom in the tribe of Besemah covering anything, then conducted analysis of the legal certainty given to the Adat law community when there is a violation committed of Adat heirloom and how the procedure is done in conducting the management of the estate so that later known the level of awareness of the law of indigenous peoples to its inheritance. The results of the research is the inheritance in indigenous peoples in the tribe of Besemah consisting of the House of Baghi, Tanah, and Keris Serunting Sakti. Then the efforts of indigenous peoples to the people of adat in preserving their inheritance is by doing traditional ceremonies that are attended by community leaders, people's people, and rural residents. As in the house Baghi there is a pillar-set ceremony (Sedekah Negah Ka Tiang), the ceremony of raising a cam (Sedekah nupload Mubungan), ceremony occupies the house (Sedekah Nunggu Ghumah), and the ceremony to test the house (Sedekah Nyimak Ghumah). In addition to the keris, the traditional ceremony is done as a ritual of bathing the Kris as an apology and forgiveness to the almighty for all the mistakes that have been done and ask for all the efforts made in order to Get ease in various things, cheap sustenance, healthy community prosperous, and safe village
\end{abstract}

Key words: Estate, customary law, indigenous peoples, Besemah people. 


\section{A. INTRODUCTION}

Adat is a reflection of the personality of a nation, is one of the incarnation of the nation's soul concerned from century to century. Therefore, every nation in this world has its own customary customs that one with the other is not the same. Precisely because of this inequality we can say that the custom is the most important element that gives identity to the nation in question. ${ }^{1}$

Within the Republic of Indonesia, the customary owned by the areas of ethnic groups is different, although the basis of the country and its nature is one, namely to its Indonesian culture. Therefore, the indigenous peoples of Indonesia are said to be "Bhineka" (different in the area of people's tribes) "Tunggal Ika" (but still one of the basic and the nature of its Indonesian). And the indigenous peoples of Indonesia that "Bhineka Tunggal Ika" is not dead, but always develop constantly moving and based on the necessity always in the state of evolution following the development process of the civilization of its people.

Every Community action is always evolving and will not be able to be accompanied if the law is only static. Although there have been written rules established by competent authorities, in fact the law in society should also conform to developments in the society itself. In addition, Adat gives confidence and belief to the public that there is a source of law in addition to legislation, because customs is a source of law is not written but also has a binding power for society.

\footnotetext{
${ }^{1}$ Surojo Wignjodipuro, 1979, Pengantar dan AzasAzas Hukum Adat, Alumni, Bandung, page 1.
}

In customary law, the customary heritage is known. Indigenous peoples have their own heritage, although not all indigenous peoples must have an heirloom, because the absence of inheritance does not mean that there is no customary law in society. Likewise in the Besemah tribe that has its own customary heritage, for example there is a magical ceremony to do laundry against the keris that is possessed by their ancestors, the magic of the Milky Way. This became one of the most interesting studies to do research.

Leopold Pospisil suggests that customary law must have four legal attributes. These four legal attributes also have social control functions or social controls. These four legal attributes consist of: ${ }^{2}$

\section{Authority attributes}

The attribute of authority determines that the cultural activity of the law is a decision made by a person or group of people who have authority or authority in society.

2. Attributes with intent to Universal adoption

Attributes with a view to universal adoption determine that the holder of authority in making such decisions is intended to be applied to the same events in the future.

\section{Obligatio attribute}

The Obligatio attribute is a concept that contains statements regarding social relations, therefore the Obligatio has two facets. The terms ranging from the

\footnotetext{
${ }^{2}$ Andry Harijanto,dkk, 2007, Bahan Ajar Hukum Adat, Fakultas Hukum UNIB, Bengkulu, page 11.
} 
personal lawbreakers, because the deeds violate the law that corrupts a condoned relationship, then it raises an obligation to improve the situation. The second facet of the person suffering from the act of the lawbreaker, then he has the right to be returned in the original situation, the right to expect action to the other party. The obligatio is a relationship between two parties which are both represented by living individuals.

\section{Sanctions attributes}

On one party, sanctions are the absolute criterion of the law, while on the other party that sanctions are not forever in the form of physical sanctions. The form of legal sanctions used of course is closely related to the group or sub-group where sanctions are used. Sanctions can be physical or socialpsycological.

Indigenous heritage belongs to customary jurisdiction. Customary law is a traditional law, because most of this customary law is not written. Traditional legal hashing can be described as follows: ${ }^{3}$

\section{Traditional law has strong togetherness.}

2. Have a religious magical pattern related to Indonesia's natural life view.

3. The system of law is covered by a concrete mind, meaning that the law is very concerned about the number and berulang-ulangnya of concrete relationships.

4. Has visual properties, meaning that the relationship of the law is deemed to occur only because it is determined by a bond that can be seen (or visible markings).

\footnotetext{
${ }^{3}$ Satjipto Rahardjo, 1980, Hukum dan Masyarakat, Angkasa, Bandung, page 155.
}

Based on this reason, it is interesting to research on the inheritance of indigenous peoples in the Besemah tribe and the efforts of indigenous peoples in the Besemah tribe to preserve their inheritance.

\section{B. RESEARCH METHODS}

In this study, researchers conducted interviews. As for the material interviewing is about the existence of heirloom in the tribe of Besemah covering anything, then conducted analysis of the legal certainty given to the Adat law community when there is a violation committed of Adat heirloom and how the procedure is done in conducting the management of the estate so that later known the level of awareness of the law of indigenous peoples to its inheritance. The research location is done in Jokoh subdistrict, Dempo Tengah subdistrict, Pagar Alam city.

\section{DISCUSSION}

\section{The inheritance of indigenous peoples at Besemah tribe}

Talking about the customary treasures of course do not loose speaking about the law of inheritance in Adat. A normative law of inheritance is a law of pluralism of law which means that the community can apply different legal provisions, as the law of inheritance can be seen from the perspective of Islamic law, the civil law governed in the Civil Code of Law (Burgelijk Wetboek), and customary law. In this study the author will examine the indigenous treasures of the tribes that are reviewed from indigenous inheritance.

The inheritance law is one part of the family system in Indonesia. Therefore, the 
base of the description of indigenous inheritance law is a starting point of the form of society and the nature of the family in Indonesia according to the lineage system. Every system of descendants that is in Indonesian society has a specificity in the laws of its heirs, which are different, namely: ${ }^{4}$

1. Patrilineal system, namely the family system that attracts the lineage of male ancestors. In this system the position and influence of the male party in the law of inheritance is very prominent, for example in Batak society. The heir is only a son because the daughter who has married in the way of "married Honest" who later entered into a family member of the husband, then she was not the heir of her parents who died.

2. Matrilineal system, namely the family system that attracts the lineage of the female ancestors. In this family system the male party did not become heir to his children. Children become heirs of the line of women/mother lines because their children are part of his mother's family, while his father is still a member of his own family, the example of this system is in Minangkabau society. However, for the Minangkabau people who have been wandering outside the original land, the condition has changed a lot.

3. Parental or Bilateral system, which is a system that draws a lineage from two sides, both from the father's side and from the mother party. In this system the position of sons and daughters in equal and parallel law. That is, both boys and girls are heirs of their parents ' estate.

\footnotetext{
${ }^{4}$ Eman Suparman, 1985, Hukum Waris Indonesia dalam Perspektif Islam, Adat, dan BW, Refika Aditama,Bandung, page 41 .
}

Besemah tribes adopted the kinship of the Patrilineal system, meaning that the Besemah tribe adopted a family system that drew the lineage of the male ancestors.

Besides the family system which is very influential to the arrangement of customary law, especially against the determination of heirs and inheritance of inherited assets, the customary law to know three systems of inheritance, namely: ${ }^{5}$

A. Individual inheritance system, which is the inheritance system that is to determine that the heirs inherited individually, for example in: Java, Batak, Sulawesi, and others;

B. Collective inheritance system, that is, the system that determines that the heirs of the inheritance of the inheritance together (collectively) because the inherited property is not able to be divided into each heir. For example, the heirloom in Minangkabau and Tanah Dati on the peninsula Hitu Ambon.

C. The system of inheritance of Mayorate, which is the system of inheritance that determines that the heirs of inheritance only inherited by a child.

Every activity of Adat law community in relation to the customary values of the ancestors chaired by the customary chairman. In the governance is headed by the head of the village at the level of Lurah. In the Besemah tribe, the customary audience is governed by the Juray institution. Juray is said to be an institution because it has devices and rules. In addition to the local stakeholder agency

${ }^{5}$ Ibid. 
which is not an indigenous people's establishment but was formed by the government of Pagar Alam as a government representative to socialize the government's customary program to the public.

The function of the Tuwe is to lead the society in the field of customs and heritage of the Serunting Sakti. Apit profile is a leader in the field of adat in every puruk. Apit profile is also in charge of the profile Tuwe in the deliberations and customs ceremonies and represents the Tuwe when absent. The murmurings replacement Apit is a special position at the level of the murmurings, but the department of Apit, in charge of representing the Tuwe visited the Lembak Puruk and Puruk Ulu if any will be discussed before being taken to a profile level meeting. Apit profile is a traditional audience at Puruk level in a hamlet. Sungut profile is tasked with assisting Apit profile in supervising the implementation of customs in each puruk. The stakeholders of the customary function as government representatives (formed by the government) to handle the customary field.

The customary treasures of the Besemah tribe are: ${ }^{6}$

\section{Baghi House}

The House of Baghi is a traditional house by the local people, called Ghumah Baghi (the house is read) which means old house. The house is physically divided into two types namely the House of Tatahan (house with ornate carvings in some parts of the house) and Rumah Gilapan (house

\footnotetext{
${ }^{6}$ Rois Leonard Arios, 2012, Bunga Rampai Budaya Sumatera Selatan Budaya Basemah di Kota Pagar Alam, BPSNT Padang Press, Padang, page 5.
}

without ornate carving in some parts of the house). While technically making, the house is divided into two types, namely the House of Padu Tiking and Rumah Padu Ampaghe. The four types of houses in terms of house structure and layout are no different. The difference is only seen on the social status of a home owner that is specific to the house of inlaid which is considered to belong to a person who is more wealth than the other. This relates to the cost of creating a more expensive inlaid house from the Gilapan house.

With the existence of the chief leader of the Adat, then all the plans relating to customary activities in the life of one hams to report the plan to the Sunnah of rnasing for the next to be offered at a direct village meeting level Led by Profile Tuwe. This meeting was done in the family home will build a house and attended by indigenous audiences, namely Profile Tuwe, murmurings profile, and Apit profile from its territory, a large family of homeowners, and close neighbors. In this meeting will be talked about all the possibilities that will happen when the house is in a certain location. As the status of ownership must be clear, the reactions of the neighbors, as well as "Visions " of the shamans about good bad location chosen.

When the talk results in a positive deal, it is followed by talks about raw materials, handyman, and house building costs. At this talk usually only attended by a large family of homeowners and neighbors close. Also included in the case of collecting building materials, contacting the artisan, and the process of building a house that includes clearing the acreage, the main pole-building, establishing a house body must involve the skipper. 
However, at this time Baghi House can no longer be found in Jokoh village but only found in the village of Pelang Kenidai Dempo District, Central of Pagar Alam. In addition, the House of Baghi can still be found in the village of Karang Dalo Central Dempo District, village Rempasai district of South Dernpo, hamlet of Pagar Jaye in Pagar Alam North around Mount Gaghe, and Hamlet Meringan District South Dempo.

\section{Land}

The residential area in Jokoh Village is a limited area of both area and customary rules on land ownership. Besemah people who embraced patrilineal customs inherited the rights of Ulayat and personal treasures to his son. Thus land ownership is fully controlled by men.

Land when associated with mastery by customary law community is called Ulayat. The land associated with this customary law is governed by the law No. 5 year 1960 concerning the basic rules of agrarian Principles article 2 paragraph (4), article (3), article 5, article 22 , and article 26.

\section{Kris Serunting Sakti}

It is believed that the people who have led and created the norms and cultural values of the Semidang tribe. The belief of the temadap of the society is also a social control tool because they believe to this moment the strength of the Serunting Sakti Rnasih still exist and keep their hamlet. One of the relics of the Serunting Sakti is a Kris that is named Tata Renggane. This Kris became one of the whole descendants of Semidang tribe elsewhere. In case of customary violations such as the action of immoral, then the Kris according to the head of Tuwe will be dirty and in the hamlet will occur several times strange events such as the flame seen burning on the house of the Lord.

Besides, the Tuwe will also get the promptings of the spirit of the puthing that is believed to be the statesman. If these signs have been seen, then the Lord Tuwe as a direct descendant (the first boy based on patrilineal) from the Serunting Sakti will find out what is happening in his community. The people who are asked will not dare to lie for fear of the curse of the Serunting Sakti when lying. If there is a citizen that has violated the customs, then immediately may will be held ceremony of clearing the hamlet through the ceremony of washing pesake (the keris).

The Kris washing ceremony must be attended by all the villagers and all citizens should also see the keris that is dirty before washing. So also the citizens who determine whether the Kris is clean washed. If all the citizens replied that they were seen and the Kris was clean, then the Kris was inserted into the holster and wrapped in a cloth to be saved again by the staff of the Tuwe.

\section{The efforts of customary law community on Besemah people in preserving its inheritance}

As mentioned above that the customary treasures of Besemah tribe are the house of Baghi, the land, and Keris Serunting Sakti. The efforts of indigenous peoples in the Besemah tribe to preserve their inheritance are:

1. House of Baghi. 
A. The ceremonial-designed ceremony (Sedekah Negah Ka Tiang)

The ceremony of raising the pole is done after the whole land of the house has been completed and clean from wild plants. The land that has been flat marked the place of the pole will be planned. The pillar of the House of Baghi bias consisted of 9 pillars, but one of them was the main pillar and the first to be pared. This pole was the pole that was first exposed to sunlight in the morning so that its position was at an angle pointing to the east. To be designed the main pole is done raising the pole. This ceremony is only a prayer event so that the construction of the house can be carried out and all workers do not get any disruption or calamity during the artisan. Likewise, the subtle creatures that may be in the location can move elsewhere so that the work of building houses and home dwellers will not be disrupted.

This ceremony is held in the morning and lasts very simple so that the participants of the ceremony is limited only to the whole family members or a spacious family of homeowners led by the family head of homeowners or invited Datuk specifically. After the main pole was designed, the ceremonial leader read the prayers and Al-Fatihah together who asked for the safety and health of both workers and homeowners. After the pole was pared, it continued the next job with the other pillars. Sometimes after the main pole is planned, it is followed by a meal together between the home owner's family and the artisan.

B. Raising ceremony (Nupload
Mubungan)

The ceremony of Mount Cam (Sedekah nupload Mubungan) is performed when the entire skeleton of a house such as a Pole, rafters, and other parts of the House will continue to install or raise the house. This ceremony is held in one day starting from 07.00 am to $16.00 \mathrm{pm}$. The materials needed in this alms are:

A) A white flag that will be mounted on a ridge that means a winning home owner manages to set up a house in one location. This flag also means describing that a person has been able to build a house assessed in terms of economics and will further raise his social status.

b) Green coconut water (niugh ijang) inserted in glass bottles that are intended so that the house that is occupied looks sweet by everyone;

c) The Linggur (pumpkin-like fruit) is a food that can not be eaten by Pelang Kenidai people.

d) Banana Mas one Bundan intended to make the house and the occupants look sweet like banana mas

e) Sugarcane the following leaf and its roots are intended as a symbol of household harmony;

f) The leaves are meant to reconcile and provide tranquility of the house occupants.

In general, the function of these materials is to prevent the builders from the danger of working on the house. Once the cam pole is mounted, the whole material is hung in the middle of the ridge. At the very top installed the white flag. After the materials are hung, then the homeowner or one of the house owner's 
family members recite the azan where the materials are hung.

During the work, the men eat banana mas that are hung on the ridge. Other ingredients are not transferred until the house is finished. As a seat for the ceremony participants, the board was installed as a seat as the House floor. The participants consisted of spacious home and family owners, Sedusun neighbors, indigenous people, and religious figures (Khatib and Datuk).

C. Occupy the house ceremony (Sedekah Nunggu Ghumah)

After the house was completed, a few days later the house owner held a charity event as Thanksgiving and a thank you to the artisan who had built his house. This ceremony is also a notice to the general public that the house that was built is already completed and already occupied.

The ceremony begins in the morning at around 09.00, starting with a meal together. Food served is a common meal served on every alms (ritual) such as goat rice '/beef/fish (depending on the ability of the party), vegetable:-Vegetable, and Lemang as dessert.

Finish the meal followed by a prayer event and a few welcome words from the host and the invitees. The event begins with a host greeting that conveys to the invitation that the house they are building has completed well and has been occupied and hope the prayers of the invitations so that the House gives the health of the inner birth to its occupants. When the house has been completed, the host usually does not allow the artisan and the other workers to come home before following the celebration. They usually stay in the new house or in their respective homes if the artisan lives a hamlet. On that occasion also the host thanked the artisan and the workers who had finished his house according to the plan he had made. This celebration is a thank you and apologise if during the work, there is a speech or act of host that does not pertain to the artisan and other workers. Likewise, all other costs or shortcomings will be settled at that time.

Through this charity, he gave the man to his home or to his house (Kabalek). To the handyman is given provision of food and other supplies such as cloth and clothes substitute clothes that have been damaged during the work. The provision of the house owner consists of:

-Rice one ibat (4-5 plates), wrapped with banana leaves as many as the workers;

-Side dish (pepes/Limpingan)

-Lemang (glutinous rice cooked in bamboo)

All the provisions were wrapped in a cloth (house owner's holster) and handed over to the head of the handyman. It belongs to the head of the handyman, but at the same moment, the head of the artisan will divide his par members as a thank you handyman who has helped him during his work. After this process is completed, the event is resumed with a greeting from the invitation, i.e. from the general public or the closest neighbor, customary device, government (RT or RW Chair), and end with a prayer from a religious figure or datuk.

D. House testing Ceremony (Sedekah Nyimak Ghumah) 
The House Test ceremony is a ceremony that is not absolutely done by homeowners. The ceremony is carried out most quickly about a Month after the house is finished or after the charity of the Ghumah. The purpose of this ceremony is to test home quality especially the floor strength.

The participants of the ceremony were all members of the family and the people of the Dusun. All participants will stomp the floor by skipping small or kicking with the soles of the feet on some house Hagian. When it is done and see the result it will be repaired again by the artisan if there is damage or by the landlord when the damaged is not too severe.

Finish testing the parts of the house, then eat together all the participants.; Food served is a common food in charity activities such as cutting goats or cows or chicken, rice, fish, vegetables, lemang, and other delicacies according to the ability of the homeowner. Before eating Hersama begins the homeowner will convey a greeting of thank you to the invitations and beg the safety prayers of the invitation to the health and safety of the house dwellers during the Occupy this House. This ceremony should not be done when the house is occupied (after the ALMS wait Ghumah) is the one who passed away in the house.

\section{Land}

Generally the land in Jokoh is a customary land owned jointly by a large family. But as the impact of the development of the population and the land abuse system that requires every land to be certified, then all existing land is already a certificate that means already owned by one person such as the name written on the certificate of land ownership. For this possession is fully controlled by the oldest son according to the customary Patriarchate in the Besemah people.

The legal ownership system, in fact, is still jointly shared for the utilization of the results. For example a land and house on it, based on customary law belongs to the oldest child and has been given a certificate on behalf of the oldest child, but in the use of the House is still the right of all members of his relatives. Likewise, the agricultural area, processing and utilization of the results can still be done by each family member so long as not to have personally.

The occurrence of proprietary law is governed by the constitution of article 22 paragraph (1), but the mandate of the UUPA for regulation governing it is further governed by government regulation. But until now, government regulations have not formed. For the existence of indigenous and customary Law Society is currently based only on the circular letter of the head of BPN No. 3/SE/IV/2014 on the Pentapan of the existence of indigenous and customary law community. Based on this SE, the establishment of indigenous and rural law communities with the provincial regulations or regional regulations of the Regency/city. Therefore, there is a good coordination between local government districts and provincial governments with the central government. If not, then the ownership of land can only be done by one person in accordance with article 19 UUPA Jo. Government regulation No. 24year 1997 on land registration. 


\section{Kris Serunting Sakti}

Other faiths that live in Besemah people are against the relics of the natural heritage that must be pured as a tribute to their ancestors. The ritual of bathing the Kris is one of the ceremonies performed by the residents of Kuteu (Dusun) together and headed by the Tuwe. Lastly, the event was called in August 2018 by the hamlet Jokoh, district Dempo Tengah previously held the Keris pick up ceremony to the hamlet of Pelang Kenidai. The Kris is believed to be a relic of the Serunting Sakti who is the ancestor of the Jokoh and Pelang Kenidai people. Jokoh and Pelang Kenidai Hamlet incorporated in Sumbai Semedang. A Kris washing ceremony should be done every year or waiting for the wangsit. If you have to wait for the time it is not fixed like the new Jokoh village community. In addition to these beliefs, Besemah people also have a variety of traditional ceremonies that reflect the daily beliefs or religion. The traditional ceremonies that they commonly do are wedding ceremonies, house building ceremonies, bathing ceremonies, Kris washing ceremonies and many more. The implementation of the ceremony has special rules and equipment and is led by certain people.

The author conducted a structured interview to Jurai Tuwe (Chairman of Adat) in Jokoh village, Mr. Iskandar. According to Pak Iskandar The Kris washing is usually done 5 years or 10 years once. However, the Kris washing is occasionally done during certain conditions. The condition in question is when the village atmosphere is not safe. Another condition is the village atmosphere that has been troubling, for example the coming of a residence tiger, many robbery, and many riots that occurred. The Kris to wash the keris came through the dream of Jurai Tuwe. Jurai Tuwe is the chairman of the Basemah tribe customary in Jokoh village. The letter contains the command "Mwash the seed" or the bias interpreted as washing the Kris. Another mention of Jurai Tuwe.

The purpose of the Kris washing is to refuse from the Balak, both large and small. The Kris washing process is found in the "Toto Renjono". Kris was kept in one of the descendants of Serunting Sakti named Guss Salih. Before the Kris was washed, there was prayer at the house of Serunting Sakti in Sukajadi. The procession of residents is praying together and also provided meals after praying in Sukajadi. After the Kris pared and reached Jokoh village. Then it was done again prayers and eating together. The procession of the Kris laundering was attended by community leaders, customary leaders, Lurah, and Camats. The Kerisyang was brought by Gus Salih to Jokoh Village, handed over to the head of the Tue to be washed. Before the washing was held again and his intention to "Nurunka keris" or to bring down the Kris equipped with offerings. It is a 2-tails chicken, and is made by the Kunjung. Then, also prepared a bowl of water, Flowers 7 rupa, mats (Lapek), and banana leaves. The Keris is washed using water on the green bamboo arrangement using water. Then the flower of seven inserted into the tube is made of green bamboo that contains water. After being watered, the Kris is placed on a banana leaf topped up and made by the keris to dry the Kris. The banana leaf should be arranged down so that the water from the Kris can descend to 
the ground. This can be interpreted by the poison from a direct Kris fell to the ground and absorbed into the soil. After drying, the Kris is then inserted into the sheath and it is wrapped again using a red turban.

After bathing keris, Jurai Tuwe conveyed his ancestor's admonitions in the form of Pantun. The belief in the old tradition still exists so that if there is a thing in their hamlet back to the old tradition as a form of problem solving they face. This ceremony is done because there are many things that are outside of human desire such as failed crops and others.

Through the ceremony to bathe their heirloom Kris apologizing and forgiveness to the almighty for all the mistakes that have been done and ask for the ridho of all the efforts made in order to get the ease in various things, cheap sustenance, society Health, and the village safe Sentosa. In addition, the author also conducted an interview against the current Striah Jokoh, Mr. Herdianto. According to him, the government in this matter Lurah, the Camat, until the mayor is very supportive of this traditional ceremony so that this traditional ceremony should be preserved to preserve and plant the values that live in the people of the tribe Besemah.

\section{CONCLUSION}

1. Not all tribes in Indonesia have customary heritage. Indigenous treasures are an inheritance of ancestors in customary law societies. Although there is no adat heirloom owned by a adat law community does not mean that customary law in the region is not a reason for the existence of customary law should not be balanced with the possession of indigenous treasures. The inheritance of indigenous peoples in the tribe of Besemah consists of the house of Baghi, Tanah, and Keris Serunting Sakti

2. Efforts of indigenous peoples in the community to preserve their inheritance is by conducting traditional ceremonies that are attended by community leaders, people's people, and rural residents. As in the house, there is a pillar-set ceremony (Sedekah Negah Ka Tiang), the raising ceremony of Bubungan (Sedekah nupload Mubungan), ceremony occupy the house (Sedekah Nunggu Ghumah), and the House testing ceremony (Sedekah Nyimak Ghumah). In addition to the keris, the traditional ceremony is done as a ritual of bathing the Kris as an apology and forgiveness to the almighty for all the mistakes that have been done and ask for all the efforts made in order to Get ease in various things, cheap sustenance, healthy community prosperous, and Dusun Aman Sentosa.

\section{E. SUGGESTIONS}

1. Recognition of the indigenous peoples of Besemah adat law is still generally regulated in the regulation of the Minister of Home Affairs No. 52 year 2014 of the Guidelines for recognition and protection of indigenous people's law, so it is hoped that the city of Pagaralam Also Forming a local regulation to the existence of the indigenous peoples ' customary laws can be protected by their rights.

2. The implementation of traditional ceremonies about the customary treasures is very important to do in order to preserve the traditional values 
of Besemah tribe, to provide assurance, then it is necessary a custom Functionarians decision that is written so that the ceremony This traditional can be done continuously.

\section{BIBLIOGRAPHY}

Andry Harijanto,dkk, 2007, Bahan Ajar Hukum Adat, Fakultas Hukum UNIB, Bengkulu.

Eman Suparman, 1985, Hukum Waris Indonesia dalam Perspektif Islam, Adat, dan BW, Refika Aditama,Bandung.

Rois Leonard Arios, 2012, Bunga Rampai Budaya Sumatera Selatan Budaya Basemah di Kota Pagar Alam, BPSNT Padang Press, Padang.

Satjipto Rahardjo, 1980, Hukum dan Masyarakat, Angkasa, Bandung.

Surojo Wignjodipuro, 1979, Pengantar dan Azas-Azas Hukum Adat, Alumni, Bandung. 